\title{
Conservation agriculture and resource management under jute (Corchorus spp.) based cropping systems in eastern India
}

\author{
Debarati Datta, R. Saha* and A. K. Ghorai \\ ICAR-Central Research Institute for Jute and Allied Fibres, Barrackpore, Kolkata 700 120, India
}

\begin{abstract}
Conservation agriculture (CA) technologies involve paradigm shift from traditional agriculture and include minimum soil disturbance, permanent soil cover through crop residues and crop diversification for achieving sustained productivity and making rational use of resources. The climate-resilient crop management technologies of $\mathrm{CA}$ reverse the degradation process inherent to the conventional agricultural practices like intensive agriculture, declining factor productivity and provide opportunities to reduce production cost, save inputs, improve soil properties, make efficient resource use and benefit the environment. For nearly two decades, several researches and policies have been disseminated that made significant multiple ecosystem services in the rice-wheat system of the Indo-Gangetic Plains. Likewise, there is a huge potential of $\mathrm{CA}$ in jute-based cropping system in eastern India, and there is an urgent need to frame policies and strategies to promote $\mathrm{CA}$ in the jute-growing regions of the country to bring sustenance in its production and quality. This article focuses on the emerging concerns due to the practice of conventional methods, and analyses the scope, constraints and research needs for $\mathrm{CA}$ and resource management in jute-based cropping systems of India.
\end{abstract}

Keywords: Conservation agriculture, economic efficiency, jute-based cropping, resource management, sustainability

ACHIEVING food and nutritional security for the burgeoning population while sustaining agricultural production system under the recent spell of depleting natural resources, negative impact of climate change, spiralling production costs and the rise in food prices have come to the forefront of global political agenda. Climate change coupled with intensive unsustainable crop production has exacerbated the constraints of agriculture which include decline in soil organic matter (SOM), soil quality deterioration, reduced water infiltration rate, surface sealing and crusting, inadequate return of organic matter to soil, pest incidence and eventual loss of crop productivity due to monocropping. Therefore, there is a pressing need for

\footnotetext{
*For correspondence. (e-mail: saharitesh74@rediffmail.com)
}

a paradigm shift in production technology through eliminating conventional agricultural practices (ploughing the soil, organic material oxidation, monoculture) for sustaining future food, feed and fibre productivity while conserving the natural resources.

Conservation agriculture (CA) is being steadily practised worldwide and covers about $\sim 8 \%$ of the arable land, i.e. $124.8 \mathrm{M}$ ha (ref. 1). India was able to accomplish food security through the Green Revolution, but traditional agriculture being highly mechanized, has resulted in the over-exploitation and misuse of natural resources coupled with indiscriminate use of inorganic chemicals, declining factor productivity, loss of biodiversity, increasing soil salinity, lowering of the groundwater table, eutrophication, environmental pollution due to greenhouse gas (GHG) emissions, pest resurgence and land degradation $^{2}$. Therefore, the success of the Green Revolution has now been masked by the drawbacks posed by it, which are a threat for promoting productive capacity of soil and crops. The eastern region of India has been in focus to usher the second Green Revolution, and its potential needs to be harnessed by advocating CA, particularly in rice-jute-based cropping system.

Conservation agriculture as defined by FAO, is an approach for managing agro-ecosystems to attain higher and sustained production levels, acceptable profits and food security for enhancing both above- and below-ground natural biological processes. $\mathrm{CA}$ is based on the three linked principles of minimum mechanical disturbance of the soil, i.e. no vertical perturbation of soil, permanent organic cover of the soil surface and crop diversification or association of crops, along with other complementary good agricultural practices of crop production. It is a potent alternative to traditional agriculture, attenuating its obstacles as it stresses on the favourable impacts of a conservative way of cultivation on soil, water and air biodiversity $^{3,4}$.

$\mathrm{CA}$, often referred to as resource-efficient agriculture aims to conserve, improve and utilize natural resources through integrated management of available soil, water and biological resources combined with external inputs to achieve a balance of agricultural, economic and environmental benefits. It promotes most soils to have a wide array of bioactivity and biodiversity, provides better soil 
structure, protects against raindrops and reduces run-off losses. Thus, CA is a win-win approach with recognized benefits of conservation goals like savings of labour, fuel, mitigation of negative climate effects, reduced operational costs and enhanced yields ${ }^{5}$.

Jute (Corchorus spp.), the golden fibre of India, is ecofriendly, biodegradable and has much higher $\mathrm{CO}_{2}$ absorption rate, which is creating new avenues for the endurance and development of the jute industry in the era of ecological concerns. Jute can sequester a significant amount of carbon in its vegetative stage, and reports confirm that 1 ha of jute crop can absorb about $15 \mathrm{t}$ of atmospheric $\mathrm{CO}_{2}$ and liberate about $11 \mathrm{Mt}$ of $\mathrm{O}_{2}$, during 120 days of growing period ${ }^{6}$. There is negative GHG emission from jute as it acts as a sink of carbon by assimilating about $5.8 \mathrm{t} \mathrm{CO}_{2}$ during its lifetime ${ }^{7}$. Barma et $a l .{ }^{8}$ from Bangladesh reported that apart from wheat, rice, maize, oilseeds and pulses, jute can be grown successfully through CA technology. Given the increasing focus on today's environmental issues, it is obvious that there is noteworthy prospect of jute crop being grown based on the principles of $\mathrm{CA}$ in India. In this background, the present article discusses the current status of research and development with respect to yield, soil health, resource use efficiency, the boon and bane of its adoption to tap new growth sources in jute-based cropping.

\section{Scope of conservation agriculture in jute-based cropping sequences}

\section{Soil quality, nutrient recycling and yield}

CA takes care of soil health, plant growth and environment ${ }^{9}$ and is being practised to meet the global food demand with minimum ecological footprint. Field experiments conducted at ICAR-Central Research Institute for Jute and Allied Fibres, Kolkata, with zero tillage (ZT), zero tillage + residue $(\mathrm{ZT}+\mathrm{R})$ along with conventional tillage (CT) (control) under the most predominant cropping systems, i.e. jute-rice-wheat/lentil/mustard systems revealed that minimum soil disturbances coupled with residue retention optimized soil properties and provided better soil environment for plant growth ${ }^{10}$. The soil residue retention under zero tillage treatment was $>30 \%$ followed by additional brown manuring practice (broadcasting of Sesbania crop @ $20 \mathrm{~kg} \mathrm{ha}^{-1}$ between rows of jute crop, grown for 30 days and then incorporated). Soil organic carbon (SOC) was positively correlated with mean weight diameter (MWD) (0.83) and available $\mathrm{N}$ (0.68) but negatively correlated with BD (-0.74). Hati et $a l .{ }^{11}$ and Bandyopadhyay et al. ${ }^{12}$ reported significant positive correlation between MWD and SOC, and \%WMSA (water stable macro-aggregates) and SOC respectively. Evaluation of soil quality index (SQI) showed better values in jute-rice-lentil (range 0.42-0.62) under zero tillage with residue (range $0.45-0.62$ ) compared to other systems, depicting significant cumulative effect of lentil crop along with zero tillage (ZT) and residue incorporation on soil quality (Figure 1). Similar findings have been reported by Kumar et al. ${ }^{13}$. Removal of surface residues and exposing the surface soil through tillage might be responsible for accelerated decomposition and reduced aggregate stability in $\mathrm{CT}$. Gallaher and Ferrer ${ }^{14}$ reported that at $0-5 \mathrm{~cm}$ soil depth, soil under no tillage contains 20-43\% more nitrogen than CT. A positive correlation $\left(R^{2}=0.64\right)$ between SQI values and jute equivalent yield (JEY) implies that the index may have practical utility in quantifying soil quality under CA. JEY among the cropping systems followed the sequence: jute-rice-lentil $\left(7.32 \mathrm{t} \mathrm{ha}^{-1}\right)>$ jute-rice-wheat $\quad\left(7.19 \mathrm{t} \mathrm{ha}^{-1}\right)>$ jute-ricemustard (6.75 $\mathrm{t} \mathrm{ha}^{-1}$ ) (Figures 2 and 3).

Summarizing the effect of conservation practices in Bangladesh, during kharif in transplanted aman rice-boro rice-jute cropping pattern with conservation machinery such as strip till planting method (ST), PTOS method (planting by power tiller-operated seeder (mixed tillage)) along with conventional tillage and broadcasting, and conventional puddling and transplanting (farmers'

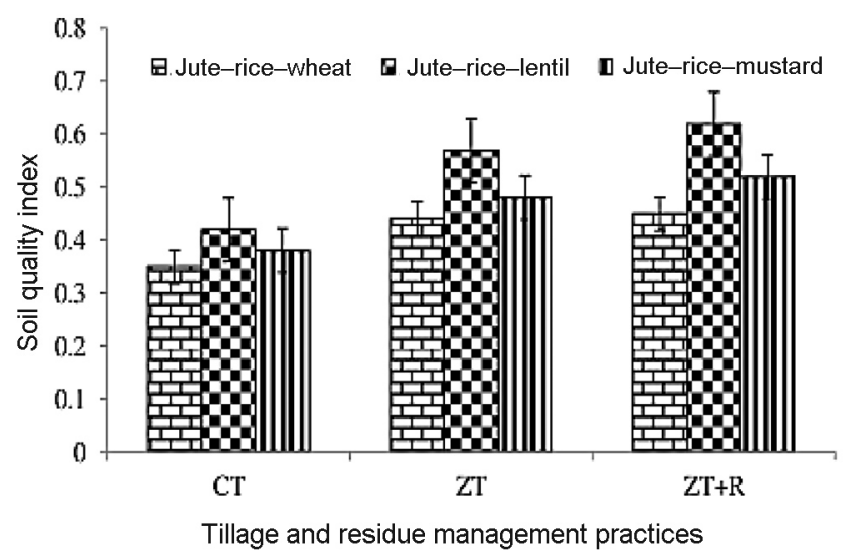

Figure 1. Soil quality under various tillage, residue management and cropping systems ${ }^{10}$.

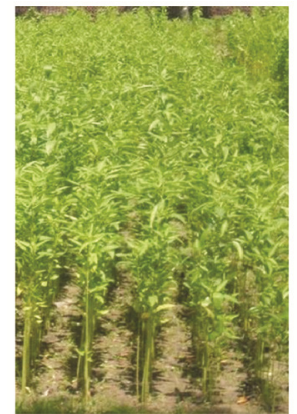

CT

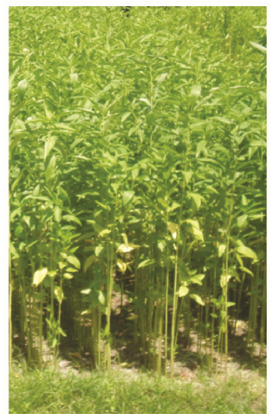

ZT

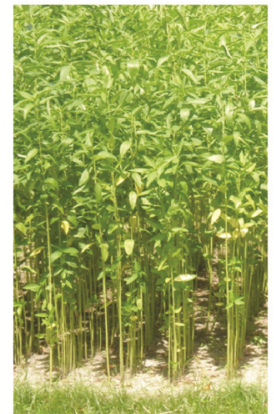

$\mathbf{Z T}+\mathbf{R}$
Figure 2. Jute crop under various tillage practices ${ }^{10}$. 


\section{REVIEW ARTICLE}

Table 1. Effect of different tillage systems on yield and yield-contributing parameters of jute at Baratia, Dumuria, Khulna, Bangladesh ${ }^{15}$

\begin{tabular}{|c|c|c|c|c|c|c|}
\hline Treatment & $\begin{array}{l}\text { Plant population } \\
\quad\left(\text { per } \mathrm{m}^{2}\right)\end{array}$ & $\begin{array}{l}\text { Plant height } \\
(\mathrm{cm})\end{array}$ & $\begin{array}{l}\text { Base diameter } \\
(\mathrm{mm})\end{array}$ & $\begin{array}{l}\text { Middle diameter } \\
\qquad(\mathrm{mm})\end{array}$ & $\begin{array}{l}\text { Stalk yield } \\
\qquad\left(\mathrm{t} \mathrm{ha}^{-1}\right)\end{array}$ & $\begin{array}{l}\text { Fibre yield } \\
\qquad\left(\mathrm{t} \mathrm{ha}^{-1}\right)\end{array}$ \\
\hline ST & $39.5 b$ & 285 & $12.8 \mathrm{~b}$ & $8.96 \mathrm{~b}$ & $5.15 b$ & $2.62 b$ \\
\hline PTOS & $36.5 b$ & 288 & $14.2 \mathrm{a}$ & $10.4 \mathrm{a}$ & $6.52 \mathrm{a}$ & $3.03 \mathrm{a}$ \\
\hline $\mathrm{CT}_{\mathrm{B}}$ & $48.0 \mathrm{a}$ & 284 & $11.9 \mathrm{~b}$ & $8.59 b$ & $4.82 b$ & $2.54 \mathrm{~b}$ \\
\hline $\mathrm{CT}_{\mathrm{L}}$ & $31.5 \mathrm{c}$ & 279 & $12.2 \mathrm{~b}$ & $8.57 b$ & $1.68 \mathrm{c}$ & $1.12 \mathrm{c}$ \\
\hline CV (\%) & 11.5 & 1.8 & 6.34 & 7.9 & 8.32 & 6.57 \\
\hline$F$-test & $* *$ & NS & $*$ & $*$ & * & $*$ \\
\hline
\end{tabular}

ST, Strip till planting method; PTOS, Planting by power tiller-operated seeder (mixed tillage); $\mathrm{CT}_{\mathrm{B}}$, Conventional tillage and broadcasting; $\mathrm{CT}_{\mathrm{L}}$, Conventional puddling and transplanting.

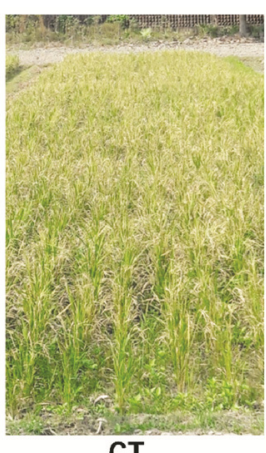

CT

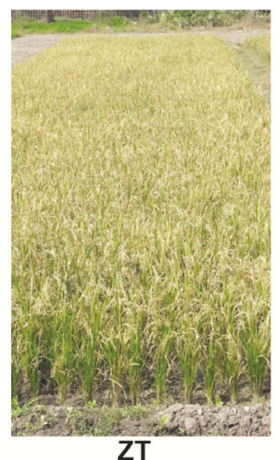

ZT

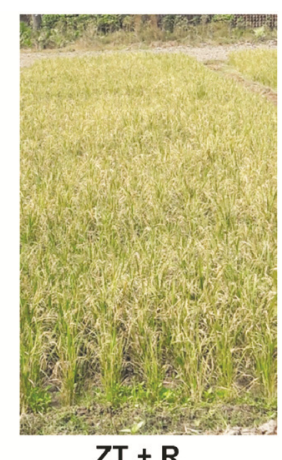

$\mathbf{Z T}+\mathbf{R}$
Figure 3. Rice crop under various tillage practices ${ }^{10}$.

practice), Hossain et al. ${ }^{15}$ concluded that significantly highest dry stalk and fibre yields were acquired from PTOS-planted jute followed by strip till and conventional tillage-cum-broadcasting jute (Table 1). The reason was enhanced plant height and diameter leading to better light and air interception. According to them, bed planting was not suitable for jute in kharif because of lodging when it becomes tall ${ }^{15}$. Transplanting of jute seedlings in muddy soil with low air movement led to lowest stalk and fibre yields.

For correct application of CA practices, several aspects have been considered by Tarafder et al. ${ }^{16}$ who reported significant higher organic carbon content $(0.84 \%)$, aggregate stability $(34.38 \%)$ and jute yield $\left(5211 \mathrm{~kg} \mathrm{ha}^{-1}\right)$ under a combination of minimum tillage, mulching and vermicompost application due to protection of encapsulated SOC inside stable aggregates from rapid oxidation ${ }^{17}$. Presence of higher lignin, polyphenol content in paddy straw leads to the formation of stable complexes with protein and makes it more resistant to decomposition. Higher available $\mathrm{N}\left(309 \mathrm{~kg} \mathrm{ha}^{-1}\right)$ and $\mathrm{P}\left(64.6 \mathrm{~kg} \mathrm{ha}^{-1}\right)$ were the consequence of vermicompost decomposition leading to mineralization of organics and nitrogen in the soil $^{18}$. Organic rice straw mulch maintained better hydrothermal regime of the soil, and increased available potassium, phosphorus and organic matter content of the soil after its decomposition ${ }^{19}$. Organic amendments on decomposition release organic acids which increases $\mathrm{P}$ availability by blocking $\mathrm{P}$ adsorption sites in the soils or through anion exchange. Besides, the organic acid could cause dissolution of P-bearing minerals in the soil and thus increase $P$ availability. Higher available $\mathrm{Fe}$ (125.23 $\left.\mu \mathrm{g} \mathrm{g}^{-1}\right), \mathrm{Mn}\left(25.13 \mu \mathrm{g} \mathrm{g}^{-1}\right), \mathrm{Cu}\left(16.98 \mu \mathrm{g} \mathrm{g}^{-1}\right)$ and $\mathrm{Zn}\left(2.58 \mu \mathrm{g} \mathrm{g}^{-1}\right)$ in the soil might be due to chelation of the micronutrient by the decomposing organics that reduced its vulnerability to fixation ${ }^{18}$.

Salahin et $a .^{20}$ conducted an experiment in Bangladesh, with ZT, strip planting (SP), bed planting (BP) and CT assigned to the main plots and two levels of crop residue retention $(20 \%$ and $50 \%$ retention) in sub-plots under rice-jute system. After the third crop cycle, minimum tillage practices (ST and ZT) showed promising results in terms of SOM, total nitrogen (TN), extractable $\mathrm{S}$ and $\mathrm{Zn}$ contents at the uppermost $0-5 \mathrm{~cm}$ soil layer. Remarkable changes in SOM content were by $24 \%$, $23 \%, 17 \%$ and $11 \%$ under ZT, ST, BP and CT practices respectively, in contrast to the initial values (Table 2). The maximum mean REY (20.4 $\left.\mathrm{tha}^{-1}\right)$ was recorded in SP, which was significantly higher that ZT $\left(18.1 \mathrm{t} \mathrm{ha}^{-1}\right)$, BP $\left(17.5 \mathrm{t} \mathrm{ha}^{-1}\right)$ and CT $\left(16.9 \mathrm{tha}^{-1}\right)$. Jute-green gram intercropping system was found to be remunerative and sustainable for resource-poor jute farmers, as it plays a pivotal role in improving farmers' economy, providing nutritional security to rural agrarian mass, nourishing soil and taking care of animal health in rural sector.

\section{Water use efficiency}

The tillage practices, crop residue management and crop rotation influence the soil hydraulic properties, moisture conservation and water storage in the soil profile because of variation in evaporation losses and utilization patterns. Crop rotation with crops having different rooting patterns combined with minimal soil disturbance in no tillage systems advocates a more extensive network of root channels and soil macropores that help in the infiltration of water to deeper layers ${ }^{21}$. In addition, the crop residue acts as a thermal insulator reducing direct insolation on the soil surface, acts as a barrier against the impact of raindrops, lowers evaporation rate and increases water conductivity $^{22}$. Singh et al. $^{23}$ reported that residue retention 
REVIEW ARTICLE

Table 2. Effects of tillage on soil organic matter (SOM), total nitrogen (TN), extractable P and $\mathrm{Zn}$ contents after three crop cycles ${ }^{20}$

\begin{tabular}{|c|c|c|c|c|c|}
\hline Tillage & $\operatorname{SOM}\left(\mathrm{t} \mathrm{ha}^{-1}\right)$ & $\mathrm{TN}\left(\mathrm{t} \mathrm{ha} \mathrm{a}^{-1}\right)$ & Extractable $\mathrm{P}\left(\mathrm{mg} \mathrm{kg}^{-1}\right)$ & Extractable $\mathrm{S}\left(\mathrm{mg} \mathrm{kg}^{-1}\right)$ & Extractable $\mathrm{Zn}\left(\mathrm{mg} \mathrm{kg}^{-1}\right)$ \\
\hline $\mathrm{ZT}$ & $10.2 \mathrm{a}$ & $0.531 \mathrm{a}$ & $10.1 \mathrm{a}$ & $17.7 \mathrm{a}$ & $0.49 \mathrm{a}$ \\
\hline SP & $10.1 \mathrm{ab}$ & $0.509 \mathrm{a}$ & $9.9 \mathrm{a}$ & $17.2 \mathrm{a}$ & $0.47 \mathrm{ab}$ \\
\hline BP & $9.6 \mathrm{~b}$ & $0.496 \mathrm{ab}$ & $9.3 b$ & $16.5 \mathrm{ab}$ & $0.44 b$ \\
\hline $\mathrm{CT}$ & $9.1 \mathrm{c}$ & $0.450 \mathrm{~b}$ & $7.8 \mathrm{c}$ & $15.6 \mathrm{~b}$ & $0.40 \mathrm{c}$ \\
\hline$P$ & $* *$ & $* *$ & $*$ & $*$ & $*$ \\
\hline Initial value & 8.2 & 0.430 & 6.1 & 14.6 & 0.32 \\
\hline
\end{tabular}

ZT, Zero tillage; SP, Strip planting; BP, Bed planting; CT, Conventional tillage.

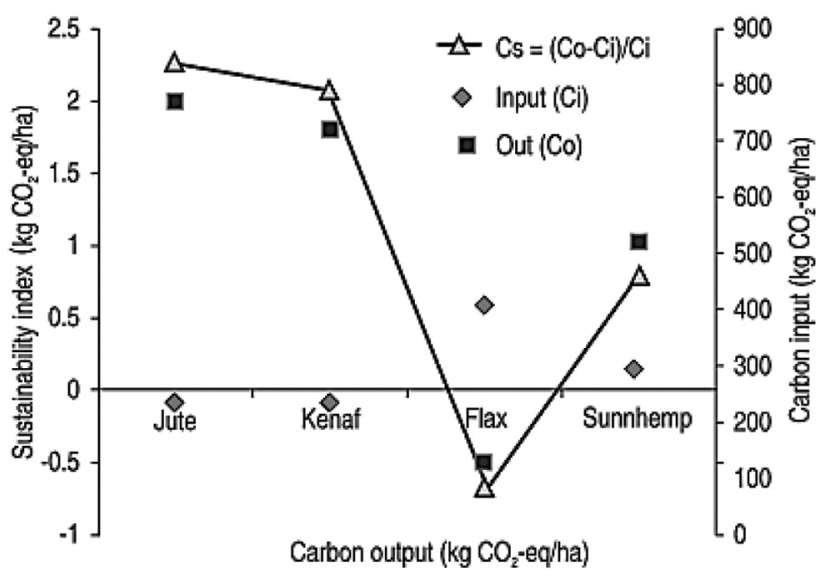

Figure 4. Carbon-based sustainability index $\left(C_{\mathrm{s}}\right)$ in fibre $\operatorname{crops}^{29}$.

was increased the water-stable aggregates of $>2 \mathrm{~mm}$ and $0.25-2.0 \mathrm{~mm}$ size by $23 \%$ and $10.1 \%$ over residue removal respectively. Consequently, soil moisture was conserved and available for a longer period of time, thus minimizing terminal drought and requirement of lifesaving irrigation ${ }^{24}$. It was also proved that in no-till plots with residue cover, the soil could maintain seed zone moisture above the wilting point for up to 5 weeks, whereas it could be maintained for 15 days in tilled plots $^{25}$. No-tillage with $60 \%$ residue cover had higher residual soil moisture than that under CT. Importantly, CA significantly reduces soil erosion and increases infiltration thereby recharging the sub-surface aquifers with precious water resources, reducing water pollution and providing clean water ${ }^{26}$. Further, CA leads to reduction in water turbidity, sediment concentration and water treatment costs than $\mathrm{CT}^{1}$. Higher water use efficiency and lower erosion can also reduce water inundation/ stagnation in low-lying areas of jute fields.

\section{Carbon sequestration}

Impact of artificial fibre production on climate change is three times more than that of the natural fibres. The primary energy required for producing artificial fibres amounts to $35 \mathrm{GJ} \mathrm{t}^{-1}$ of fibre, which is seven times higher than that of bast fibres. On an average, manufacturing of $1 \mathrm{t}$ of synthetic fibre products has $20-50 \%$ higher carbon footprint and an impact of $1.7 \mathrm{t} \mathrm{CO}_{2}$ compared to bast fibres $^{27}$. On the other hand, GHG emission in the production of natural fibre crops (from the field to the fibre factory) usually ranges between 0.5 and $0.7 \mathrm{t}$ of $\mathrm{CO}_{2}$ per tonne of natural fibre. In the context of anthropogenic GHGs emissions into the atmosphere, system sustainability can be assessed by evaluating the temporal changes in output/input ratios of carbon using a holistic appro$\mathrm{ach}^{28}$. Among the fibre crops, the carbon-based sustainability index for jute was highest (2.27) due to better carbon use efficiency (Figure 4) and the carbon footprint had been estimated as $566 \mathrm{~kg} \mathrm{CO}_{2} \mathrm{t}^{-1}$ of jute ${ }^{29}$. Since a major share of the total emission was recorded by fertilizers, substituting mineral fertilizers by organic ones may further curtail the carbon footprint of jute.

It has been estimated that jute retting adds about $0.00915 \mathrm{Tg} \mathrm{CH}_{4}$ to the atmosphere. The retting duration and thereby methane emission can be reduced using microbial consortium with pectinolytic and hemicellulolytic organisms like Clostridium tertium, C. aurantibutyricurn, C. felsinum, Bacillus subtilis, B. polymyxa and Aspergillus niger, and activators like $0.05 \%$ magnesium phosphate. Since methane generation is much less in the case of ribbon retting for jute, its adoption at a large scale could help improve the eco-status of the crop.

The net ecosystem exchange (NEE) of $\mathrm{CO}_{2}$ in high biomass-producing jute agro-ecosystem as measured by the open path eddy covariance (EC) technique was positive at sowing to germination stage (highest NEE of $-126.86 \mathrm{~g} \mathrm{C} \mathrm{m}^{-1}$ or $-465.15 \mathrm{~g} \mathrm{CO}_{2} \mathrm{~m}^{-1}$ at fibre development stage), and thereafter it became negative up to the maturity stage of the crop. The negative values of NEE indicate carbon intake by jute crop when the rate of photosynthesis is more than the ecosystem respiration, and vice versa ${ }^{30}$.

\section{Weed control efficiency}

About $40 \%$ of the total cost of cultivation is for the weeding process alone ${ }^{31}$. Fibre yield loss up to $90 \%$ has been recorded if not weeded at the proper time. In many of the 
CA systems, weed control represents one of the major setbacks and thus necessitates knowledge about weed biology and ecology, and their physical and chemical control $^{32}$. The weed dynamics has changed significantly over the years under surface residue condition. Under no disturbance, weed seeds tend to accumulate and are expected to emerge from the top layer. During the initial period of zero/minimum tillage practice, annual weeds pose a problem till the exhaustion of weed seed bank in the surface soil $(0-2 \mathrm{~cm})$. After their exhaustion, annual weeds get suppressed significantly as deep-buried weed seeds can hardly come out of the surface soil. Furthermore, the surface-lying weed seeds are subjected to decay through various management practices and predation ${ }^{33}$. Sometimes, surface residue decomposition secretes allelochemicals which inhibit the emergence of germinating weeds. After 3-5 years of cropping under zero-tillage conditions, annual species get reduced while perennial weeds can flourish due to their vegetative propagating material $^{34}$. Saha et al. ${ }^{10}$ reported higher density of broadleaved weeds in CT compared to no tillage (NT); however, it was at par with no tillage with additional crop residue $(\mathrm{NT}+\mathrm{R})$. Cynodon dactylon, a perennial grassy weed showed significantly higher density under NT system, whereas the density of Cyperus rotundus did not vary significantly among different tillage systems. Comparatively, total weed population was found to be more in NT. Hence, strategic weed management along with preventive and curative measures is crucial. Controlling emerged weeds through pre- and post-emergence herbicides or mechanical control, and managing the leftover weeds through non-selective herbicides are the recommended strategies for their management in $\mathrm{CA}^{35,36}$. Since most of the seeds remain on the surface in CA, they can be controlled by stale seed-bed technique followed by application of non-selective herbicide. CRIJAF Nail weeder operation in jute field at 4-5 days after jute emergence (on field capacity soil) reduces weeds by $80-85 \%$, and helps in soil mulching.

In well-drained soils, mulching with rice straw at $10 \mathrm{t} \mathrm{ha}^{-1}$ reduced weed dry matter by $75 \%$. Besides, companion cropping of jute with red amaranthus + radish and pulse inclusion as intercrop smothered sedges and dicots up to $54 \%$ (ref. 37). Moreover, jute + green gram provides nutritional security, improves soil health and strengthens the economy of poverty-stricken jute farmers. Higher weed control efficiency (68-82\%) was obtained in inter-cropping system compared to the conventional and cumbersome manual weeding twice $(63.62 \%)$. Benefitcost ratio (BCR) under this system varied between 2.20 and 2.46 compared to 1.80 in manual weeding. Green gram in intercropping system produced $2 \mathrm{tha}^{-1}$ of waste (average nitrogen), which is equivalent to $10 \mathrm{t}$ of farmyard manure ${ }^{38}$. This can also be used as nutritious fodder and when incorporated in jute soil will improve its health.

\section{Soil biodiversity}

Soil biodiversity is the variability of living biota, soil macro- and micro-fauna and flora within a habitat involved in agricultural activity. CA practices are key for maintaining the layer of organic matter in the topsoil which provides substrate, energy and habitat to the residing soil biota. Soil micro- and macro-flora mainly in the form of bacteria and fungi play a crucial role in soil health enrichment by decomposing organic matter, and recycling nutrients ${ }^{39}$. Improved microclimate, addition of root exudates and increased $\mathrm{C}$ availability due to residue retention have resulted in higher soil microbial biomass and proliferation of other enzymatic activities ${ }^{40}$. Researchers suggest that CA practices help increase earthworm abundance by $127 \%$ compared to conventional agriculture $^{41}$. Earthworms, the ecosystem engineer and nature's plough, are a significant part of macrofauna in the soil and enrich soil properties by breaking down leaf litter and binding the soil with their excretion. Jute has been used in phytoextraction studies related to heavy metal toxicity ${ }^{42}$ due to its distinct biological and physiological activities ${ }^{43,44}$. Saleem et al. ${ }^{42}$ concluded that jute is a hyper-accumulator species of different heavy metals from soil, water and field, and can be used as a bioindicator. Having a strong antioxidant defence system, it can overcome the effect of oxidative stress caused by metal toxicity. After phytoremediation, the jute biomass can be utilized for the production of value-added by-products like sheet, roof tiles, chairs and tables.

\section{Energy use efficiency and fuel savings}

By adoption of conservation tillage practices, reduction of energy takes place due to reduced field operations. It has been reported that $16 \%$ of global fossil-fuel emission can be reduced due to its adoption. Hossain et al. ${ }^{15}$ reported that the effective field capacities of ST and PTOS operations, and power tiller for dryland and wetland (puddling) tillage were found to be $0.098,0.099,0.100$ and $0.096 \mathrm{ha} \mathrm{h}^{-1}$ respectively, whereas, the field efficiencies were estimated to be $69.78 \%, 71.33 \%, 84.66 \%$ and $81.99 \%$ respectively. Fuel consumption for ST and PTOS operations was the same $\left(13.901 \mathrm{ha}^{-1}\right)$, whereas in case of power tiller for dry and wetland preparation it was 56.60 and $41.10 \mathrm{l} \mathrm{ha}^{-1}$ respectively. Single pass was enough for tilling and jute seeds planting in the ST and PTOS methods.

\section{Economic efficiency}

For jute cultivation, the highest BCR was obtained from PTOS (2.54) followed by ST (2.31) and CT-cumbroadcasting (2.20) methods ${ }^{15}$. The lowest BCR was 


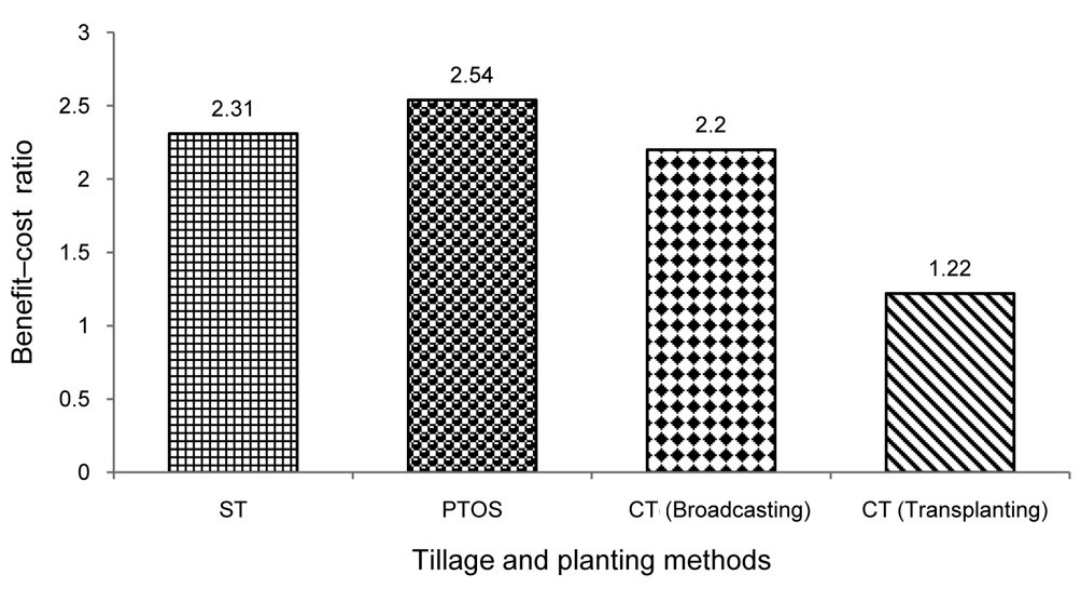

Figure 5. Benefit-cost ratio of jute cultivation by different tillage and planting methods ${ }^{15}$.

found from traditional tillage and manual seedling transplanting (1.22; Figure 5).

Behera et $a l .{ }^{45}$ reported that inclusion of medicinal plants in the jute cropping sequence like jute-kharif riceashwagandha recorded net returns of ₹ $186,831 \mathrm{ha}^{-1}$ followed by asalio ( $₹ 148,426 \mathrm{ha}^{-1}$ ), whereas traditional crop potato registered highest net returns of $₹ 247,204 \mathrm{ha}^{-1}$. The maximum BCR of 2.22 was recorded in case of jute-kharif rice-ashwagandha compared to traditional cropping sequence of jute-kharif rice-potato (1.89). Considering the system economics, jute-stevia-autumn rice recorded highest net returns of $₹ 524,467 \mathrm{ha}^{-1}$, which was $306.68 \%$ higher compared to traditional crop tomato $\left(₹ 128,961 \mathrm{ha}^{-1}\right)^{45}$. The maximum BCR (2.61) was recorded in the jute-stevia-autumn rice cropping sequence.

\section{Challenges in promotion of conservation agriculture technology}

CA as an impending paradigm for raising crops in a jutebased sequence will necessitate several inventive features to address the challenges which impede wide-scale adoption of the approach. Successful adoption of CA principles in jute-based cropping sequence in eastern India calls for improvement, standardization and adoption of quality farm machinery for jute seeding, crop harvesting and management strategies. Suitability of machinery depends on farmer's plot size, availability of local repair shops and skilled manpower. High cost of machinery and low returns from agricultural produce discourage investments in agriculture. Besides, resource-poor farmer and small landholders face the risk of crop failure with new technology. Research-extension-farmers linkage should be well established for the CA technologies. Further, transfer and policy support should be accelerated for custom hiring. Hobbs and Govaerts ${ }^{46}$ reported that a major hurdle for CA and its successful adoption is in convincing the farmers about zero and minimum tillage. Being complex in nature, site-specific knowledge of different ecologies has been another setback to the spread of the CA system ${ }^{4}$. This implies that an entire package of practices for crop production, including sowing and harvesting, water, nutrients and pest management needs to be developed, assessed and coordinated in the context of new frameworks and systems. CA is a sustainable technology and indeed in many situations, results of resource improvement occur gradually, and paybacks come only with time.

\section{Conclusion}

Challenges of conventional agriculture accentuate the requirement and urgency to address tactics by which threats to farming by virtue of natural resource degradation, soaring production costs and devastating consequences of climate change can be met effectively. CA can reverse the ill-effects of resource degradation, decreasing produce costs, GHG emission and making agricultural interventions economically, ecologically and socially sustainable. A shift in paradigm has become a prerequisite as a result of the widespread resource degradation which accompanied the past strategies to boost production with no concern for resource integrity. Studies illustrate that the jute-based cropping system in eastern India has a huge potential for enactment of conservation practices; likewise the rice-wheat cropping system in northwestern India. It is thus imperative to have the farmers involved with demonstration and experiments in their own fields to accelerate the process of adoption of CA. Furthermore, there is a pressing need of multidisciplinary approach to reorient farming practices for producing more with less cost by adopting less vulnerable options and pathways. Hence, jute cultivation with conventional agriculture practices does not fetch sustainable gains. Hence CAbased crop management solutions adapted to local needs will play a critical role for ecological upliftment. 


\section{REVIEW ARTICLE}

1. http://www.fao.org/ag/ca/6c.html

2. Ghosh, P. K., Das, A., Saha, R., Kharkrang, E., Tripathi, A. K., Munda, G. C. and Ngachan, S. V., Conservation agriculture towards achieving food security in North East India. Curr. Sci., 2010, 99(7), 915-921.

3. Derpsch, R., Friedrich, T., Kassam, A. and Li, H., Current status of adoption of no till farming in the world and some of its main benefits. Int. J. Agric. Biol. Eng., 2010, 3, 1-25.

4. Derpsch, R. et al., About the necessity of adequately defining no-tillage - a discussion paper. In Proceedings of the 5th World Congress on Conservation Agriculture, Brisbane, Australia, 26-29 September 2011.

5. Roy, K. C., Haque, M. E., Justice, S., Hossain, I. and Meisner, C. A., Development of tillage machinery for conservation agriculture in Bangladesh. AMA-Agr. Mech. Asia Af., 2009, 11(2), 58.

6. IJSG Jute Matters, International Jute Study Group (IJSG), Dhaka, Bangladesh, April 2013, 1(5).

7. Rahman, M. M. and Bala, B. K., Ecological and environmental sustainability of jute production systems in Bangladesh: life cycle assessment. SAARC J. Agric., 2009, 7, 51-66.

8. Barma, N. C. D. et al., Adoption of power tiller operated seeder in rice wheat cropping system. Annual Research Report 2013-14, Wheat Research Centre, Bangladesh Agricultural Research Institute, Dinajpur, Bangladesh, 2014, pp. 248-253.

9. Bhattacharyya, R. et al., Tillage and irrigation effects on soil aggregation and carbon pools in the Indian sub-Himalayas. Agron. $J ., 2013, \mathbf{1 0 5}(1), 101-112$.

10. Saha, R., Paswan, A., Majumdar, B., Barman, D., Behera, M. S., Mazumdar, S. P. and Sarkar, S., Soil quality under tillage and residue management in jute (Corchorus spp.) based cropping systems of Indo-Gangetic Plains. Int. J. Curr. Microbiol. Appl. Sci., 2018, 7(11), 133-140.

11. Hati, K. M., Biswas, A. K., Bandyopadhyay, K. and Misra, A. K., Effect of post-methanation effluent on soil physical properties under a soybean-wheat system in a Vertisol. J. Plant Nutr. Soil Sci., 2004, 167, 584-590.

12. Bandyopadhyay, K. K., Misra, A. K., Ghosh, P. K. and Hati, K. M., Effect of integrated use of farmyard manure and chemical fertilizers on soil physical properties and productivity of soybean. Soil Till. Res., 2010, 110(1), 115-125.

13. Kumar, A. et al., Short-term effect of conservation agriculture practices on soil quality of a vertisol in central India. Appl. Biol. Res., 2017, 19(1), 26-34.

14. Gallaher, R. N. and Ferrer, M. B., Effect of no-tillage vs conventional tillage on soil organic matter and nitrogen contents. Commun. Soil Sci. Plant Anal., 1987, 18(10), 1061-1076.

15. Hossain, M. I., Amin, M. N., Alam, M. M., Saha, C. K., Kalita, P. K., Hansen, A. C. and Mottalib, M. A., Conservation machinery for planting of mungbean and jute in the southern region of Bangladesh. In ASABE Annual International Meeting, American Society of Agricultural and Biological Engineers, 2018; doi:10. 13031/aim.201800679/.

16. Tarafder, H. K., Mani, P. K. and Ray, M., Combined effect of minimum tillage, mulching and vermicompost application on jute. Bioscan, 2017, 12(1), 493-497.

17. Six, J. A. E. T., Elliott, E. T. and Paustian, K., Soil macroaggregate turnover and microaggregate formation: a mechanism for $\mathrm{C}$ sequestration under no-tillage agriculture. Soil Biol. Biochem., 2000, 32(14), 2099-2103.

18. Chaudhury, J., Mandal, U. K., Sharma, K. L., Ghosh, H. and Mandal, B., Assessing soil quality under long-term rice-based cropping system. Commun. Soil Sci. Plant Anal., 2005, 36, 1141-1161.

19. Ghorai, A. K., Analysis of pointed gourd (Trichosanthes dioica L.) cultivation with and without rice straw mulch: a case study. SAARC J. Agric., 2004, 2, 73-87.

20. Salahin, N., Jahiruddin, M., Islam, M. R., Bell, R. W., Haque, M. E. and Alam, M. K., Changes in soil organic matter, plant nutrients and system productivity under conservation agricultural practices in the rice-jute cropping system. In Second Conference on Conservation Agriculture for Smallholders, Mymensingh, Bangladesh, 14-16 February 2017.

21. Kacemi, M., Water conservation, crop rotations, and tillage systems in semiarid Morocco. Ph.D. dissertation. Colorado State University, CO, USA, 1992, p. 200.

22. Zhang, Y. et al., No-tillage with continuous maize cropping enhances soil aggregation and organic carbon storage in Northeast China. Geoderma, 2018, 330, 204-211.

23. Singh, V. K., Dwivedi, B. S., Singh, S. K., Majumdar, K., Jat, M. L., Mishra, R. P. and Rani, M., Soil physical properties, yield trends and economics after five years of conservation agriculture based rice-maize system in north-western India. Soil Till. Res., 2016, 155, 133-148.

24. López-Garrido, R., Deurer, M., Madejón, E., Murillo, J. M. and Moreno, F., Tillage influence on biophysical soil properties: the example of a long-term tillage experiment under Mediterranean rainfed conditions in South Spain. Soil Till. Res., 2012, 118, 52-60.

25. Mrabet, R., Saber, N., El-Brahli, A., Lahlou, S. and Bessam, F., Total, particulate organic matter and structural stability of a Calcixeroll soil under different wheat rotations and tillage systems in a semiarid area of Morocco. Soil Till. Res., 2001, 57, 225-235.

26. Govaerts, B., Sayre, K. D., Goudeseune, B., De Corte, P., Lichter, K., Dendooven, L. and Deckers, J., Conservation agriculture as a sustainable option for the central Mexican highlands. Soil Till. Res., 2009, 103(2), 222-230.

27. PwC, Life cycle assessment of CFGF-Continuous Filament Glass Fibre Products, GlassFibreEurope, Europe, 2012; http://www.glass-fibreeurope.eu/wp-content/uploads/GFE-201202-LCA-report.pdf

28. Lal, R., Follett, R. F., Stewart, B. A. and Kimble, J. M., Soil carbon sequestration to mitigate climate change and advance food security. Soil Sci., 2007, 172, 943-956.

29. Singh, A. K., Kumar, M. and Mitra, S., Carbon footprint and energy use in jute and allied fibre production. Indian J. Agric. Sci., 2018 , 88(8), 1305-1311.

30. Barman, D. et al., First report of net ecosystem $\mathrm{CO}_{2}$ exchange in jute-agroecosystem in India. In National Seminar on Natural Fibre Resource Management for Sustainable Developments, NINFET, Kolkata, 2-3 February 2019, p. 3.

31. Ghorai, A. K., De, R., Chowdhury, H., Majumdar, B., Chakraborty, A. and Kumar, M., Integrated management of weeds in raw jute. Indian J. Weed Sci., 2013, 45(1), 47-50.

32. Baghel, J. K., Das, T. K., Mukherjee, I., Nath, C. P., Bhattacharyya, R., Ghosh, S. and Raj, R., Impacts of conservation agriculture and herbicides on weeds, nematodes, herbicide residue and productivity in direct-seeded rice. Soil Till. Res., 2020, 201, 104634.

33. Farooq, M., Flower, K. C., Jabran, K., Wahid, A. and Siddique, K. H., Crop yield and weed management in rainfed conservation agriculture. Soil Till. Res., 2011, 117, 172-183.

34. Das, T. K. et al., Conservation agriculture in rice-mustard cropping system for five years: impacts on crop productivity, profitability, water-use efficiency, and soil properties. Field Crops Res., 2020, 250, 107781.

35. Nath, C. P. et al., Tillage and nitrogen management effects with sequential and ready-mix herbicides on weed diversity and wheat productivity. Int. J. Pest Manage., 2018, 64(4), 303-314.

36. Susha, V. S., Das, T. K., Nath, C. P., Pandey, R., Paul, S. and Ghosh, S., Impacts of tillage and herbicide mixture on weed interference, agronomic productivity and profitability of a maize wheat system in the northwestern Indo-Gangetic Plains. Field Crops Res., 2018, 219, 180-191.

37. Ghorai, A. K., Integrated weed management of jute (Corchorus olitorius). Indian J. Agron., 2008, 53(2), 149-151. 
REVIEW ARTICLE

38. Ghorai, A. K., Mukesh, K. and Kar, C. S., Intercropping in jute with green gram for weed smothering. Indian J. Weed Sci., 2016, 48(3), 343-344.

39. Palm, C., Blanco-Canqui, H., DeClerck, F., Gatere, L. and Grace, P., Conservation agriculture and ecosystem services: an overview. Agric. Ecosyst. Environ., 2014, 187, 87-105.

40. Spedding, T. A., Hamel, C., Mehuys, G. R. and Madramootoo, C. A., Soil microbial dynamics in maize-growing soil under different tillage and residue management systems. Soil Biol. Biochem., 2004, 36(3), 499-512.

41. Kladivko, E. J., Tillage systems and soil ecology. Soil Till. Res., 2001, 61, 61-76.

42. Saleem, M. H., Fahad, S., Rehman, M., Saud, S., Jamal, Y., Khan, S. and Liu, L., Morpho-physiological traits, biochemical response and phytoextraction potential of short-term copper stress on kenaf (Hibiscus cannabinus L.) seedlings. Peer J., 2020, 8, e8321.

43. Ogunkunle, C. O., Ziyath, A. M., Adewumi, F. E. and Fatoba, P. $\mathrm{O}$., Bioaccumulation and associated dietary risks of $\mathrm{Pb}, \mathrm{Cd}$, and $\mathrm{Zn}$ in amaranth (Amaranthus cruentus) and jute mallow (Corchorus olitorius) grown on soil irrigated using polluted water from Asa River, Nigeria. Environ. Monit. Assess., 2015, 187, 281.

44. Abubakari, M., Moomin, A., Nyarko, G. and Dawuda, M. M., Heavy metals concentrations and risk assessment of roselle and jute mallow cultivated with three compost types. Ann. Agric. Sci., 2017, 62, 145-150.

45. Behera, M. S, Kundu, D. K., Satpathy, S., Jha, A. K. and Naik, R. $\mathrm{K}$., Scope and opportunity of growing medicinal and aromatic plants in jute based cropping system. In National Conference of Stakeholders on Conservation, Cultivation, Resource Development and Sustainable Utilization of Medicinal Plants of North Eastern India, Nagaland University, Lumami, 6-7 March 2019, p. 36.

46. Hobbs, P. R. and Govaerts, B., How conservation agriculture can contribute to buffering climate change. In Climate Change and Crop Production (ed. Reynolds, M. P.), CAB International, 2010, pp. 177-199.

ACKNOWLEDGEMENT. We thank the Indian Council of Agricultural Research, New Delhi for providing logistic support with necessary library and other infrastructural facilities during this study.

Received 24 July 2020; accepted 5 August 2020

doi: $10.18520 / \mathrm{cs} / \mathrm{v} 119 / \mathrm{i} 6 / 926-933$ 